\title{
Zircon survival in shallow asthenosphere and deep lithosphere
}

\section{Anastassia Y. Borisova ${ }^{1,2, *}$, Ilya N. Bindeman ${ }^{3,4}$, Michael J. Toplis ${ }^{5}$, Nail R. Zagrtdenov ${ }^{1}$,

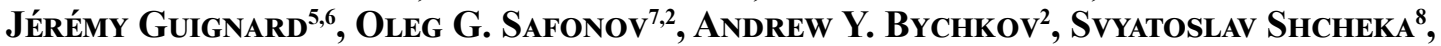 Oleg E. Melnik ${ }^{9}$, Marion Marchelli ${ }^{1}$, And Jerome Fehrenbach ${ }^{10}$}

\author{
${ }^{1}$ Géosciences Environnement Toulouse (GET), Université de Toulouse, CNRS, IRD, UPS, France, 14 Avenue E. Belin, 31400 Toulouse, France \\ ${ }^{2}$ Geological Department, Lomonosov Moscow State University, Vorobievu Gory, 119899, Moscow, Russia \\ ${ }^{3}$ Geological Sciences, University of Oregon, 1275 East 13th Street, Eugene, Oregon, U.S.A. \\ ${ }^{4}$ Fersman Mineralogical Museum, Leninsky Prospekt 18b, 115162 Moscow, Russia \\ ${ }^{5}$ Institut de Recherche en Astrophysique et Planétologie (IRAP) UPS OMP-CNRS-CNES 14 Avenue E. Belin, 31400 Toulouse, France \\ ${ }^{6}$ CNRS, UMR 6112, Université de Nantes, Laboratoire de Planétologie et Géodynamique, Nantes, France \\ ${ }^{7}$ Korzhinskii Institute of Experimental Mineralogy, 142432, Chernogolovka, Moscow Region, Russia \\ ${ }^{8}$ Bavarian Research Institute of Experimental Geochemistry and Geophysics (BGI), University of Bayreuth, 95440 Bayreuth, Germany \\ ${ }^{9}$ Institute of Mechanics, Lomonosov Moscow State University, 1 Michurinskii prosp, 119192, Moscow, Russia \\ ${ }^{10}$ Institut de Mathématique de Toulouse, Université Paul Sabatier 118, route de Narbonne, 31062, Toulouse, France
}

\begin{abstract}
Zircon $\left(\mathrm{ZrSiO}_{4}\right)$ is the most frequently used geochronometer of terrestrial and extraterrestrial processes. To shed light on question of zircon survival in the Earth's shallow asthenosphere, hightemperature experiments of zircon dissolution in natural mid-ocean ridge basaltic (MORB) and synthetic haplobasaltic melts have been performed at temperatures of $1250-1300^{\circ} \mathrm{C}$ and pressures from $0.1 \mathrm{MPa}$ to $0.7 \mathrm{GPa}$. Zirconium measurements were made in situ by electron probe microanalyses (EPMA) at high current. Taking into account secondary fluorescence effects in zircon-glass pairs during EPMA, a zirconium diffusion coefficient of $2.87 \mathrm{E}-08 \mathrm{~cm}^{2} / \mathrm{s}$ was determined at $1300{ }^{\circ} \mathrm{C}$ and $0.5 \mathrm{GPa}$. When applied to the question of zircon survival in asthenospheric melts of tholeiitic basalt composition, the data are used to infer that typical $100 \mu \mathrm{m}$ zircon crystals dissolve rapidly $(\sim 10 \mathrm{~h})$ and congruently upon reaction with basaltic melt at pressures of $0.2-0.7 \mathrm{GPa}$. We observed incongruent (to crystal $\mathrm{ZrO}_{2}$ and $\mathrm{SiO}_{2}$ in melt) dissolution of zircon in natural mid-ocean ridge the basaltic melt at low pressures $<0.2 \mathrm{GPa}$ and in the haplobasaltic melt at $0.7 \mathrm{GPa}$ pressure. Our experimental data raise questions about the origin of zircon crystals in mafic and ultramafic rocks, in particular, in shallow oceanic asthenosphere and deep lithosphere, as well as the meaning of the zircon-based ages estimated from these minerals. The origin of zircon in shallow (ultra-) mafic chambers is likely related to the crystallization of intercumulus liquid. Large zircon megacrysts in kimberlites, peridotites, alkali basalts, and carbonatite magmas suggest fast transport and short interaction durations between zircon and melt. The origin of zircon megacrysts is likely related to metasomatic addition of $\mathrm{Zr}$ into the mantle as an episode of mantle melting should eliminate them on geologically short timescales.
\end{abstract}

Keywords: Zircon, mineral dissolution, asthenosphere, lithosphere, basaltic melt, experiment

\section{INTRODUCTION}

Zircon is the most frequently used mineral for dating terrestrial and extraterrestrial rocks (e.g., Valley et al. 2014a) using a variety of isotopes in the U-Th-Pb system (Schmitt et al. 2014). Furthermore, zircon has high closure temperatures for a wide range of elements (and their isotopes), making this mineral well suited for reconstructing sources and formation conditions. For example, Ti content is used for temperature estimates (Watson et al. 2006) while $\mathrm{O}$ and $\mathrm{Hf}$ isotopic compositions and trace element contents are commonly employed to provide insight into the source of zircon crystals and their magmatic or/and hydrothermal protoliths (e.g., Iizukaa et al. 2015; Valley et al. 2014a).

\footnotetext{
* E-mail: anastassia.borisova@get.omp.eu. Orcid 0000-0001-6373-726X.
}

Open access: Article available to all readers online.
The use of zircon as a petrogenetic tool requires knowledge of the stability field of this mineral, in addition to quantification of solubility limits and crystallization/dissolution rates at relevant $P-T$ conditions and fields of melt composition. Experimental work to determine zircon solubility, dissolution rates and diffusion coefficients of Zr in silicate liquids began in the early 1980's, but was concentrated on felsic and intermediate compositions of variable $\mathrm{H}_{2} \mathrm{O}$ contents at high temperatures and pressures (Watson 1982; Harrison and Watson 1983; Ellison and Hess 1986; Baker and Watson 1988; Baker et al. 2002; LaTourrette et al. 1996; Nakamura and Kushiro 1998; Mungall et al. 1999; Koepke and Behrens 2001; Lundstrom 2003; Watson et al. 2006; Rubatto and Hermann 2007; Behrens and Hahn 2009; Burnham and Berry 2012; Boehnke et al. 2013; Zhang and Xu 2016; Holycross and Watson 2016, 2018; Shao et al. 2018; Borisov and Aranovich 2019). In contrast, there are few experimental studies on basaltic systems, an exception be- 
ing the study of Dickinson and Hess (1982) on lunar systems, and more recent studies of synthetic terrestrial basaltic melts (Boehnke et al. 2013; Holycross and Watson 2016; Shao et al. 2018; Borisov and Aranovich 2019) and dunites (Anfilogov et al. 2015).

Interest in more mafic systems has been spurred by growing evidence for the presence of zircon grains in a wide range of terrestrial mafic and ultramafic rocks such as diorites, gabbros and gabbroids, peridotites, kimberlites, dunites, chromitites, garnet-pyroxenites, dolerites, and including spectacularly large grains of zircon in carbonatites (e.g., Bea et al. 2001; Belousova et al. 2002, 2015; Kaczmarek et al. 2008; Kostitsyn et al. 2009, 2012, 2015; González-Jiménez et al. 2017; Bychkova et al. 2019a, 2019b; Bea et al. 2020 and references therein) as well as in basaltic meteorites (Ireland and Wlotzka 1992; Humayun et al. 2013; Valley et al. 2014b; Iizukaa et al. 2015; Bellucci et al. 2019). However, there is a current debate concerning the formation mechanisms of zircon in terrestrial mafic and ultramafic rocks that can reach $3.2 \mathrm{Ga}$ in age. $\mathrm{Hf}$ and $\mathrm{O}$ isotope composition coupled with $\mathrm{U}-\mathrm{Th}-\mathrm{Pb}$ geochronology has led to various ideas, including delamination/recycling of continental lithosphere, direct involvement of fragments of continental lithosphere, or an ancient event of fluid-rock interaction followed by long-duration storage at mantle conditions (Kostitsyn et al. 2009, 2015; Ashwal et al. 2017; Bea et al. 2020 and references therein).

However, current experimental data in mafic systems are sparse and sometimes contradictory, and generally insufficient to distinguish between these different formation scenarios. For example, reaction with fluids, silicate melts and and/or other minerals (e.g., olivine, chromite), may lead to modifications of the primary zircon elemental and isotope signatures through diffusion or dissolution-precipitation (Geisler et al. 2007; Bea et al. 2018), but there are no experimental data on the survival of zircon and preservation of $\mathrm{Pb}-\mathrm{U}-\mathrm{Th}-\mathrm{O}$-Ti-REE signatures at high temperature-pressure-volatile concentration conditions in mafic and ultramafic systems. These gaps in knowledge prevent robust interpretation of the ages derived from zircon in terrestrial and extraterrestrial rocks.

In light of the fact that interaction of zircon with natural, terrestrial basaltic liquid has never been studied experimentally, and with the overall aim of providing constraints for a general model of zircon stability in natural shallow asthenospheric melts of basaltic composition, an experimental program has been initiated to con- strain the solubility limit and dissolution kinetics of zircon at high pressure and temperature in mafic systems. In this first contribution we present the results of interaction between natural Mud Tank zircon and natural and synthetic basaltic and haplobasaltic melts at $1250-1300^{\circ} \mathrm{C}$ at pressures from $0.1 \mathrm{MPa}$ to $0.7 \mathrm{GPa}$.

\section{MeThODS}

\section{Starting materials}

The zircon crystals used in this study are from the $\sim 730$ Ma Mud Tank carbonatites (Crohn and Moore 1984; Gain et al. 2019) provided as crystals $\sim 1 \mathrm{~cm}$ in size by Sebastien Meffre (UTAS, Hobart, Australia). These crystals were first prepared as doubly polished $\sim 1000 \mu \mathrm{m}$ thick sections, then made into smaller double-polished chips by slight pressing of the section. The mid-ocean ridge basalt (MORB) glass used in our experiments is a typical moderately differentiated (8.2 $\mathrm{wt} \%$ of $\mathrm{MgO}, \mathrm{M}=3.3 ; \mathrm{G}=2.5$, where $\mathrm{M}$ and $\mathrm{G}$ are factors controlling solubility of zircon in silicate melts, e.g., Harrison and Watson 1983; Gervasoni et al. 2016 and references therein, Supplementary Material ${ }^{1}$ ) glassy tholeiitic basalt (number 3786/3) from Knipovich ridge of the Mid-Atlantic Ridge sampled by dredging during 38th Research Vessel Adademic Mstislav Keldysh expedition (Sushchevskaya et al. 2000). The MORB glass (that contains no traces of olivine and/or chromite phenocrysts) has been crushed to powder ( $<100 \mu \mathrm{m}$ glass size $)$.

The haplobasatic glass, corresponding the anorthite-diopside eutectic in the system $\left(\mathrm{CaO}-\mathrm{MgO}-\mathrm{Al}_{2} \mathrm{O}_{3}-\mathrm{SiO}_{2}\right)$ was synthetized using mixtures of reagent grade oxides and carbonates $\left(\mathrm{SiO}_{2}, \mathrm{Al}_{2} \mathrm{O}_{3}, \mathrm{MgO}, \mathrm{CaCO}_{3}\right)$ following the method of Toplis et al. (1994).

\section{Experimental techniques}

The reaction of natural Mud Tank zircon with basaltic liquids has been investigated at pressures from $0.1 \mathrm{MPa}$ to $0.7 \mathrm{GPa}$ corresponding to the depths of crustal basaltic chamber (up to $20 \mathrm{~km}$ ), typical of mafic magma transport conditions in oceanic settings. Seven experimental runs have been completed in this pressure range, at temperatures in the range $1250-1300^{\circ} \mathrm{C}$ and low ratios of zircon to basalt (0.04 to 0.16 ) (Table 1, Fig. 1).

Experiments were performed in $\mathrm{Au}_{80} \mathrm{Pd}_{20}$ capsules into which a double-polished zircon chip was placed at the bottom, the upper part of the capsule being filled with basaltic glass powder. Starting materials were weighed carefully to control zircon/ melt ratio. Distilled water ${ }^{\mathrm{MQ}}$ was added in one experiment (Z7) to study the effect of hydrous basalt (Table 1). This water was introduced with a micro-syringe to the basaltic powder when the sample was already loaded into the capsule. Because of the fast kinetics of zircon dissolution at high temperatures and to avoid the complete dissolution of zircon chip, run durations had to be shorter than the time necessary to reach oxygen fugacity equilibrium with piston-cylinder double-capsule techniques using mineral buffers ( $48 \mathrm{~h}$ : Matjuschkin et al. 2015). The redox conditions in our kinetic experiments are thus considered to be controlled by the initial $\mathrm{Fe}^{2+} / \mathrm{Fe}^{3+}$ ratios of the natural samples used as starting materials (MORB glass), possibly affected by partial exchange of $\mathrm{Al}_{2} \mathrm{O}_{3}$ with pressure media (in piston-cylinder experiments). The redox conditions established were estimated to range from $\mathrm{FMQ}(+1.5)$ to $\mathrm{FMQ}(+3.6)$ (where values indicate logarithmic units compared to the FMQ, fayalite-magnetitequartz buffer) (Borisova et al. 2020). These redox conditions were estimated from

TABLE 1. Pressure-temperature-redox conditions of experiments on zircon dissolution in natural basaltic and synthetic haplobasaltic melt

\begin{tabular}{|c|c|c|c|c|c|c|}
\hline $\begin{array}{l}\text { Sample } \\
\text { number }\end{array}$ & Techniques $^{\mathrm{a}}$ & $\begin{array}{c}\text { Conditions (pressure, } \\
\text { temperature, } \\
\text { redox conditions) }\end{array}$ & $\begin{array}{c}\text { Duration } \\
\text { (hours) }\end{array}$ & $\begin{array}{l}\text { Type of basalt and } \\
\text { initial mass of Zrn } \\
\text { to basalt to water }\end{array}$ & $\begin{array}{c}\text { Observed final phases } \\
\text { (Bdy zone thickness in } \mu \mathrm{m} \text { ) }\end{array}$ & $\begin{array}{l}\text { Interface melt } C_{o} \\
\text { content } \mathrm{Zr}(\mathrm{ppm})^{\mathrm{c}}\end{array}$ \\
\hline$\overline{Z 1}$ & BGI, PC & $1300^{\circ} \mathrm{C}, 0.5 \mathrm{GPa}$ & $5 \mathrm{~h}$ & Zrn to BAS 0.075 & Partially dissolved zircon (PDZ) Zrn, $\mathrm{L}_{\text {bas }}$ & $20840 \pm 348$ \\
\hline $\mathrm{Z2}$ & IRAP, G & $1300^{\circ} \mathrm{C}, 0.1 \mathrm{MPa}, \mathrm{FMQ}$ & $1 \mathrm{~h} 15 \mathrm{~min}$ & Zrn to BAS 0.086 & PDZ, Bdy, $\mathrm{L}_{\text {bas }}(80 \pm 20 \mu \mathrm{m})$ & N.A. \\
\hline Z3 & IRAP, G & $1300^{\circ} \mathrm{C}, 0.1 \mathrm{MPa}, \mathrm{FMQ}$ & $15 \mathrm{~min}$ & Zrn to BAS 0.142 & PDZ, Bdy, $\mathrm{L}_{\text {bas }}(10 \mu \mathrm{m})$ & N.A. \\
\hline Z4 & KIEM, PC & $1300^{\circ} \mathrm{C}, 0.7 \mathrm{GPa}$ & $5 \mathrm{~h}$ & Zrn to BAS 0.037 & $L_{\text {bas }}$ & - \\
\hline Z6 & KIEM, PC & $1300^{\circ} \mathrm{C}, 0.7 \mathrm{GPa}$ & $5 \mathrm{~h}$ & Zrn to AnDi 0.157 & $P D Z, B d y, L_{\text {bas }}(100 \pm 30 \mu \mathrm{m})$ & N.A. \\
\hline $\mathrm{Z7}$ & KIEM, PC & $1300^{\circ} \mathrm{C}, 0.7 \mathrm{GPa}$ & $5 \mathrm{~h}$ & Zrn to AnDi $0.097 ; \mathrm{H}_{2} \mathrm{O}=7.0$ wt $\%$ & PDZ, Bdy, $L_{\text {bas }}(10 \mu \mathrm{m})$ & N.A. \\
\hline $\mathrm{Z} 10$ & KIEM, IHPV & $1250^{\circ} \mathrm{C}, 0.2 \mathrm{GPa}$ & $5 \mathrm{~h}$ & Zrn to BAS 0.115 & PDZ, $\mathrm{L}_{\text {bas }}$ & $23438 \pm 554$ \\
\hline
\end{tabular}

a BGI = Bavarian Research Institute of Experimental Geochemistry and Geophysics (BGI), Bayreuth, Germany; IRAP = Institut de Recherche en Astrophysique et Planétologie (IRAP), Toulouse, France; KIEM = Korzhinskii Institute of Experimental Mineralogy, Chernogolovka, Russia. PC=piston cylinder; G = gas-mixing furnace at one atmosphere pressure; IHPV = internally heated pressure vessel.

${ }^{\mathrm{b}} \mathrm{BAS}=$ natural basaltic glass; $\mathrm{AnDi}=$ haplobasaltic glass; $\mathrm{FMQ}=$ fayalite-magnetite-quartz redox buffer; $\mathrm{PDZ}=$ partially dissolved zircon; Bdy = baddeleyite associated with $\mathrm{SiO}_{2}$-rich glass; $\mathrm{L}_{\text {bas }}=$ basaltic glass.

'Interface melt concentration in parts per million $\left(C_{\mathrm{o}}\right)$ (corresponding to zircon solubility) calculated taking into account the secondary fluorescence effect only for experiments with partially dissolved zircon (PDZ) and linear interface between the zircon and glass. N.A. = not analyzed. Standard deviations are expressed for $\mathrm{Z1}$ and $\mathrm{Z10}$ based on the first four to six measurements nearby zircon crystal. 

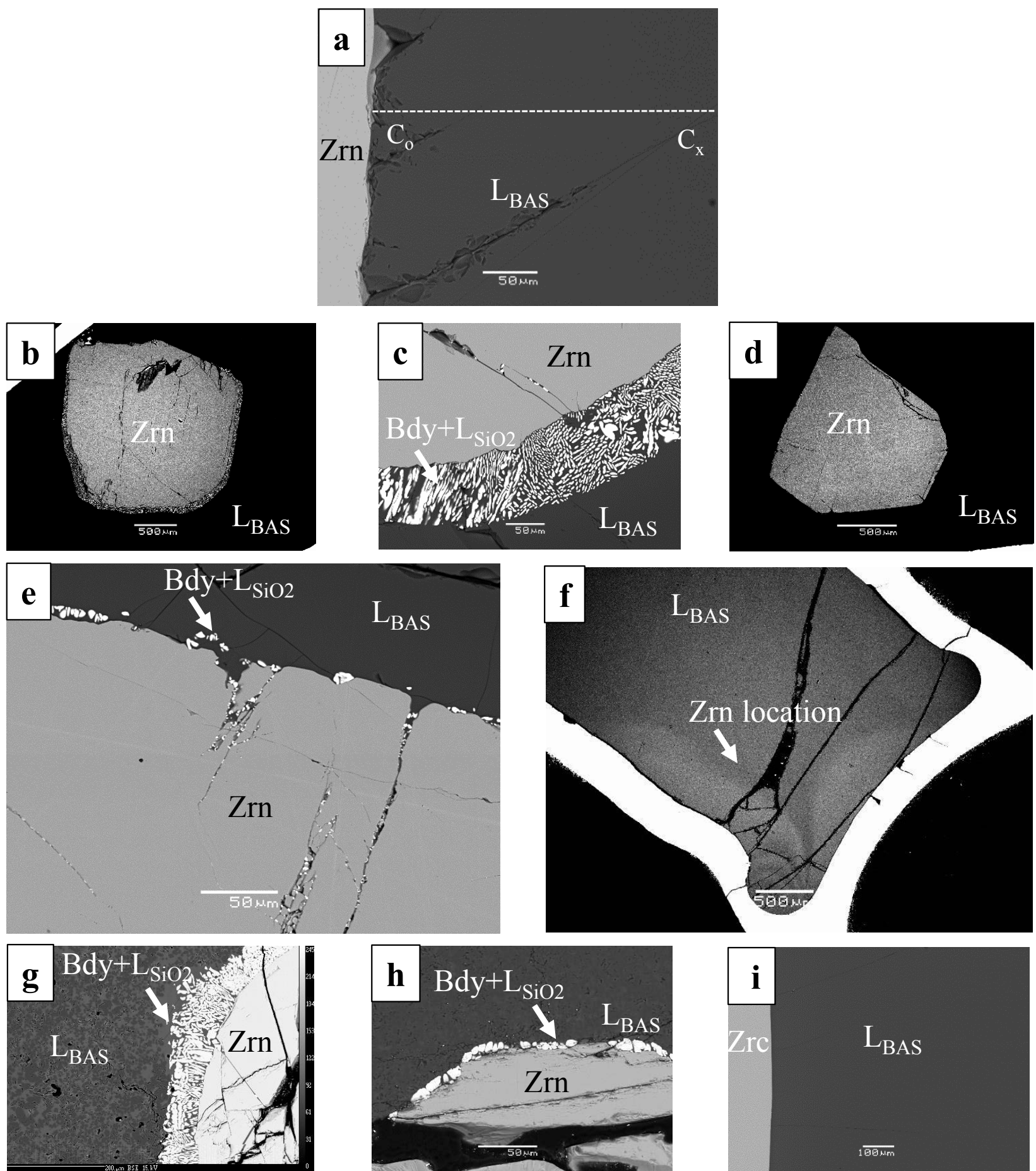

Figure 1. (a) Backscattered electron image of Z1 sample, demonstrating congruent dissolution of zircon (Zrn) in natural basaltic melt at 0.5 $\mathrm{GPa}$. (b and c) Backscattered electron image of Z2 sample illustrating incongruent zircon dissolution in natural basaltic melt. A reaction with basaltic melt at $0.1 \mathrm{MPa}$ causes zircon replacement by baddeleyite and $\mathrm{SiO}_{2}$-rich melt. (d and e) Backscattered electron image of $\mathrm{Z} 3$ sample demonstrating incongruent zircon dissolution in natural basaltic melt. A reaction with basaltic melt at $0.1 \mathrm{MPa}$ causes zircon replacement by baddeleyite (Bdy) and liberation of $\mathrm{SiO}_{2}$-rich melt $\left(\mathrm{L}_{\mathrm{SiO}_{2}}\right)$. (f) $\mathrm{Z} 4$ sample: the bulk zircon dissolution in natural basaltic melt at $0.7 \mathrm{GPa}$ according to the congruent mechanism. (g) Backscattered electron image of Z6 sample illustrating incongruent zircon dissolution in haplobasaltic melt. A reaction with the melt at $0.7 \mathrm{GPa}$ causes zircon replacement by baddeleyite and liberation of $\mathrm{SiO}_{2}$-rich melt. (h) Backscattered electron image of $\mathrm{Z7}$ sample illustrating incongruent zircon dissolution in haplobasaltic melt. A reaction with the melt at $0.7 \mathrm{GPa}$ results in zircon replacement by baddeleyite and $\mathrm{SiO}_{2}$-rich melt $\left(\mathrm{L}_{\mathrm{SiO}_{2}}\right)$. (i) Backscattered electron image of $\mathrm{Z} 10$ sample, demonstrating congruent dissolution of zircon (Zrn) in natural basaltic melt at $0.2 \mathrm{GPa}$. 
the olivine-chromite assemblages using the equations of Ballhaus et al. (1991) and from the mole fraction of ferric iron $\mathrm{Fe}^{3+}$ obtained in the basaltic glass by XANES (X-ray absorption near edge structure).

Two piston-cylinder systems were used in our experiments. The experiment (Z1) used the Max Voggenreiter end-loaded Boyd-England piston-cylinder apparatus at the Bavarian Research Institute of Experimental Geochemistry and Geophysics (BGI), Bayreuth, Germany. Talc cells 3/4 inch in diameter with Pyrex sleeves were used. A tapered graphite furnace was inserted in each cell (Fig. 2a). Alumina $\left(\mathrm{Al}_{2} \mathrm{O}_{3}\right)$

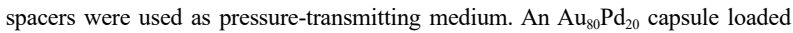
with starting materials was set in the central part of the assembly. A $20 \%$ pressure correction was applied for the friction between the talc cell and pressure vessel. A molybdenum disulfide $\left(\mathrm{MoS}_{2}\right)$ lubricant was introduced to minimize the friction. The temperature in the upper part of the capsules was controlled by a EUROTHERM (2404) controller via either $\mathrm{W}_{3} \mathrm{Re}_{97} / \mathrm{W}_{25} \mathrm{Re}_{75}$ (type D) or $\mathrm{Pt}_{6} \mathrm{Rh}_{94} / \mathrm{Pt}_{30} \mathrm{Rh}_{70}$ (type B) thermocouple accurate to $\pm 0.5^{\circ} \mathrm{C}$. The uncertainty on pressure was estimated to be $\pm 0.04 \mathrm{GPa}$. The sample was compressed to $0.5 \mathrm{GPa}$ during a period of $20 \mathrm{~min}$ and then heated up to the run temperature $\left(1300{ }^{\circ} \mathrm{C}\right)$ at a rate of $100{ }^{\circ} \mathrm{C} / \mathrm{min}$. The samples were maintained at run conditions for the desired duration, then quenched by switching off the power supply. Decompression then lasted $20 \mathrm{~min}$ to $2 \mathrm{~h}$. The quench rate to room temperature was up to $80^{\circ} \mathrm{C} / \mathrm{min}$.

Experiments (Z4, Z6, Z7) used the end-loaded Boyd-England piston-cylinder apparatus at the Korzhinskii Institute of Experimental Mineralogy, Chernogolovka, Russia. Standard talc-Pyrex cells $3 / 4$ inch in diameter, equipped with tube graphite heaters and inserts made of $\mathrm{MgO}$ ceramics were used as pressure-transmitting medium (Fig. 2b). The pressure at elevated temperatures was calibrated against two reactions of brucite $=$ periclase $+\mathrm{H}_{2} \mathrm{O}$ and albite $=$ jadeite + quartz equilibria. A pressure correction $(12 \%)$ was introduced for the friction between the cell and hard-alloy vessel. To minimize friction, a $\mathrm{Pb}$ foil and molybdenum disulfide $\left(\mathrm{MoS}_{2}\right)$ lubricant were used. $\mathrm{Au}_{80} \mathrm{Pd}_{20}$ capsules with starting mixtures were mounted in the central parts of the cells. The temperature in the upper part of the capsules was controlled to $\pm 1{ }^{\circ} \mathrm{C}$ using a MINITHERM controller via a $\mathrm{W}_{95} \mathrm{Re}_{5} / \mathrm{W}_{80} \mathrm{Re}_{20}$ thermocouple insulated by mullite and $\mathrm{Al}_{2} \mathrm{O}_{3}$ without pressure correction. For the Pyrex-bearing assemblies, the sample was heated to $550-600{ }^{\circ} \mathrm{C}$ at low confining pressure $(0.15-0.2 \mathrm{GPa})$ for a few minutes to soften the Pyrex glass, then both temperature and pressure were increased simultaneously up to the desired run conditions. The uncertainty on pressure was estimated to be $\pm 0.04 \mathrm{GPa}$. Samples were maintained at run conditions for desired durations then quenched by switching off the power supply. The quench rate was $100-200{ }^{\circ} \mathrm{C} / \mathrm{min}$.

Experiments $\mathrm{Z} 2-\mathrm{Z} 3$ used a vertical gas-mixing furnace at one atmosphere pressure, $1300^{\circ} \mathrm{C}$ and controlled oxygen fugacity at IRAP, Toulouse, France. Redox conditions in the furnace were controlled by mixtures of $\mathrm{CO}$ and $\mathrm{CO}_{2}$ corresponding to the fayalite-magnetite-quartz (FMQ) buffer. The closed, but unsealed, $\mathrm{Au}_{80} \mathrm{Pd}_{20}$ capsules loaded with starting materials were held on a Pt wire $(0.3 \mathrm{~mm}$ in diameter) and introduced into the hot spot of the gas-mixing furnace. Samples were rapidly quenched $\left(\sim 1000^{\circ} \mathrm{C} / \mathrm{s}\right)$ by dropping the sample into the cold zone of the furnace, in the $\mathrm{CO}-\mathrm{CO}_{2}$ atmosphere, by melting a thin Pt suspension wire with an electric shortcut. After evacuation of the $\mathrm{CO}$, the samples were recovered and mounted in epoxy and polished with $\mathrm{SiC}$ papers.

For the experiment $\mathrm{Z10}$, we used an internally heated gas pressure vessel at the Korzhinskii Institute of Experimental Mineralogy, Chernogolovka, Russia. The pressure in the system was created by pure Ar gas. The system was heated by a furnace with two windings (to minimize the thermal gradient). The temperature was controlled by a TRM-101 OVEN controller through two S-type $\left(\mathrm{Pt}_{90} \mathrm{Rh}_{10} \mathrm{vs} \mathrm{Pt}_{100}\right)$ thermocouples. The thermocouples were mounted at the top and close to the bottom of the run hot spot to monitor the temperature gradient. The duration of experiment was $5 \mathrm{~h}$ and the experiment was quenched by switching off the furnace. The pressure during the quench was maintained constant down to $550^{\circ} \mathrm{C}$, and then slowly released. The cooling rate from 1250 to $1000^{\circ} \mathrm{C}$ was $167^{\circ} \mathrm{C} / \mathrm{min}$, and then $90^{\circ} \mathrm{C} / \mathrm{min}$ down to $550^{\circ} \mathrm{C}$. Runs $\mathrm{Z5}, \mathrm{Z8}$, and Z9 were unsuccessful because of technical issues. After the runs, all successful run capsules were cut in two parts using a diamond saw, mounted in epoxy, and then polished using $\mathrm{SiC}$ papers and diamond pastes.

\section{Microanalytical methods}

To study the trace element profile of $\mathrm{Zr}$ in the reaction zones we used electron probe microanalysis (CAMECA SX-Five). Major element analyses of minerals and glasses (Fig. 3, Supplementary Material ${ }^{1}$ ) and sample imaging were made at the Géosciences Environnement Toulouse (GET, Toulouse, France) laboratory and at the Centre de Microcaractérisation Raimond Castaing (Toulouse, France). The main experimental phases (baddeleyite, zircon, and glasses) in the samples were identified by the EDS technique using a scanning electron microscope (SEM) JEOL JSM-6360 LV with energy-dispersive X-ray spectroscopy (EDS) in GET, Toulouse, France.

\section{a}

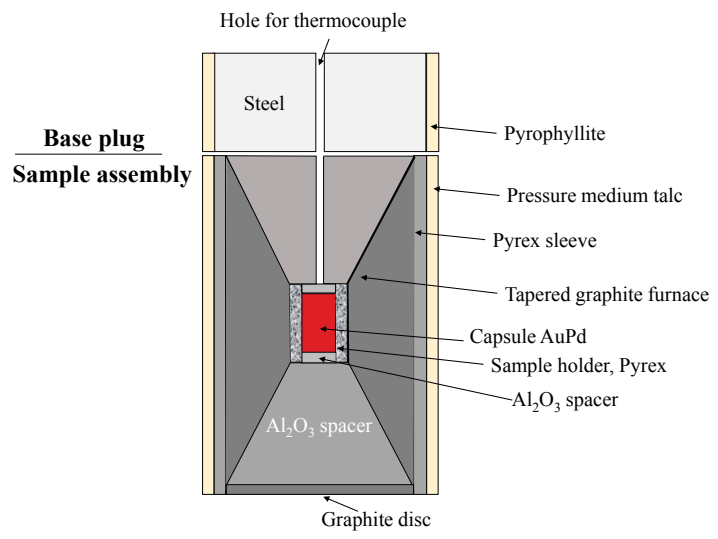

b

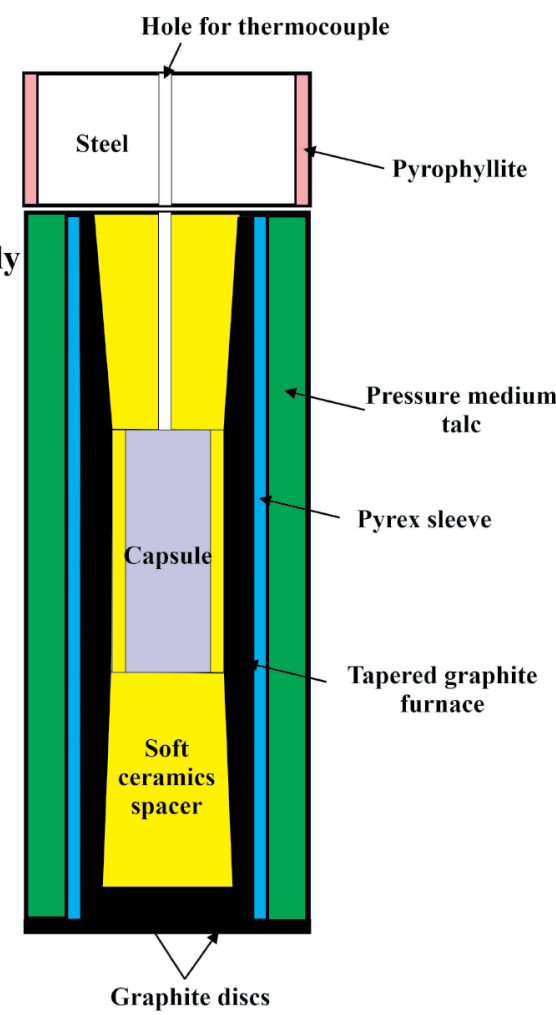

Figure 2. (a) Principal schema of assemblage of piston cylinder applied at BGI (Germany). (b) Principal schema of assemblage of piston cylinder applied at KIEM (Russia).

Major and minor $(\mathrm{Zr})$ elements in the crystals and glasses were analyzed using a CAMECA SX-Five microprobe in Centre Castaing, Toulouse, France. For the electron microprobe, operating conditions were: an accelerating voltage $15 \mathrm{kV}$, currents of $20 \mathrm{nA}$ for the major elements depending on the resistance of the material under the electron beam, and $100 \mathrm{nA}$ for the minor $\mathrm{Zr}$. Focused $(\sim 2 \mu \mathrm{m})$ beam conditions were used for the major and trace $(\mathrm{Cr}, \mathrm{Zr})$ element analyses of the glass phases. The following synthetic and natural standards were used for calibration: natural albite (for $\mathrm{Na}$ ), natural corundum $(\mathrm{Al})$, natural wollastonite $(\mathrm{Si}, \mathrm{Ca})$, natural sanidine $(\mathrm{K})$, synthetic pyrophanite $(\mathrm{Mn}, \mathrm{Ti})$, natural hematite $(\mathrm{Fe})$, natural periclase $(\mathrm{Mg})$, synthetic $\mathrm{Cr}_{2} \mathrm{O}_{3}$ $(\mathrm{Cr})$, and a reference natural zircon ( $\mathrm{Zr}$ ) provided by the Micro-Analysis Consultants Ltd. Element and background counting times were $5 \mathrm{~s}$ for $\mathrm{Na}$ and $\mathrm{K}$ and $10 \mathrm{~s}$ for other major elements, whereas peak counting times were $120 \mathrm{~s}$ for $\mathrm{Cr}$ and $240 \mathrm{~s}$ for $\mathrm{Zr}$. The detection limit was $70 \mathrm{ppm}$ for $\mathrm{Cr}$ and $\mathrm{Zr}$, this value being derived from the Cameca SX Five software based on the MPI-DING standard glasses. The synthetic 


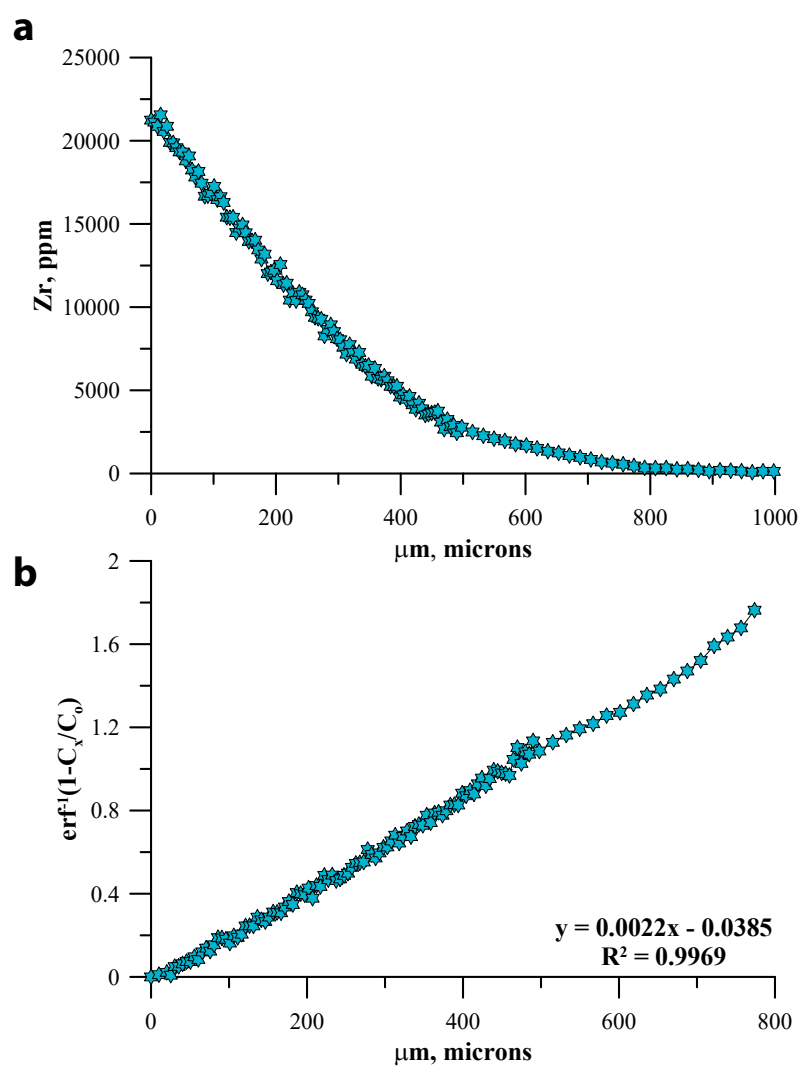

Figure 3. (a) The measured $\mathrm{Zr}$ contents vs. distance (in micrometers) from the zircon crystal in the $\mathrm{Z} 1$ sample $\left(0.5 \mathrm{GPa}, 1300^{\circ} \mathrm{C}, 5 \mathrm{~h}\right.$, Table 1$)$. (b) The corrected $\mathrm{Zr}$ profile in the $\mathrm{Z1}$ sample as the function of $\operatorname{erf}^{-1}(1-$ $\mathrm{C}_{\mathrm{x}} / \mathrm{C}_{\mathrm{o}}$ ) vs. distance (in micrometers) from the zircon crystal, suggesting zircon dissolution to be controlled by $\mathrm{Zr}$ diffusion in the basaltic melt. The uncertainty of the $\mathrm{Zr}$ concentrations (in parts per million) are in the limit of $5 \%$ relative standard deviation (RSD).

reference MPI-DING glasses of mafic and ultramafic composition (KL2-G, ML3B-G, GOR132-G, GOR128-G, Jochum et al. 2006) obtained from natural rock powders were analyzed as unknown samples to monitor the accuracy of the major and trace element analyses. The accuracy estimated on the reference glasses ranges from 0.5 to $5 \%(1 \sigma \mathrm{RSD}=$ relative standard deviation), depending on the element contents in the reference glasses. The starting MORB glass containing $0.56 \mathrm{wt} \% \mathrm{H}_{2} \mathrm{O}$ was analyzed according to the method of Bindeman et al. (2012).

\section{Secondary fluorescence effect and kinetic modeling}

Given that our overall aim is to model the behavior of zircon in natural systems, we need to extract relevant parameters from our experimental data that can be used in generalized numerical models of dissolution. In this respect, there are two fundamental parameters that control mineral dissolution: (1) the composition of liquid that is saturated in the phase of interest (that can be simplified to the concentration of a limiting element, in our case $\mathrm{Zr}$, at the crystal-liquid interface), and (2) the diffusion coefficient of that limiting element in the liquid. For both of these issues, a potential complication is secondary fluorescence during microprobe analyses that can introduce a spatially variable signature of the element of interest around host crystals (Borisova et al. 2018). Particular attention must thus be paid to eliminate this analytical artifact.

When possible, the interface melt content $\left(C_{0}\right)$ was obtained from all experiments. The linear interface between the zircon grain and glass allows subtraction of the secondary fluorescence effect and to get the correct $\mathrm{Zr}$ concentrations in the interface glasses (Table 1; Fig. 1, Supplementary Materials' ${ }^{1}$ ). An estimate of the $\mathrm{Zr}$ diffusion coefficient was extracted from one diffusion profile of the sample $Z 1$ following the method of Harrison and Watson (1983). For that, $\mathrm{Zr}$ (parts per million) profiles perpendicular to the zircon-glass interface in the Z1 sample were measured, correcting for secondary fluorescence effects measured between zircon and the same (MORB) basaltic glass (Borisova et al. 2018). The corrected profile taking into consideration of the effect was obtained by linear interpolation of the secondary fluorescence effect with the function "numpy.interp" of Python language (ver. 1.17). (e.g., Oliphant 2006) and by simple subtraction from the measured Zr concentration. The mathematic transformation of the corrected $\mathrm{Zr}$ contents in the profiles to the error function $\left(\mathrm{erf}^{-1}\right)$ correlates linearly with the distance from the interface with a slope of 0.0022 (Fig. 3, Supplementary Material ${ }^{1}$ ), suggesting diffusional control of the $\mathrm{Zr}$ distribution due to zircon dissolution in the basaltic melt according to the criterion given by Harrison and Watson (1983). Unfortunately, there is no way to extract the diffusion coefficient values from experiments where zircon dissolves incongruently, compared to congruent dissolution in natural basaltic system at $\geq 0.2 \mathrm{GPa}$.

Kinetic modeling of the bulk dissolution of a spherical zircon was completed using the MATLAB software of Bindeman and Melnik (2016) using spherical coordinates with the extracted diffusion coefficient $D_{\mathrm{Zr}}=2.87 \mathrm{E}-08 \mathrm{~cm}^{2} / \mathrm{s}$ at $1300{ }^{\circ} \mathrm{C}$ and $0.5 \mathrm{GPa}$ (Supplementary Materials ${ }^{1}$ ). The parameters used in the calculations were the interface concentration of $\mathrm{Zr}$ in the basaltic melt of $20840 \pm 104 \mathrm{ppm}$ and the initial $\mathrm{Zr}$ concentration of $94.3 \mathrm{ppm}$ in the starting basaltic melt (Borisova et al. 2020).

\section{RESULTS}

Z1 and Z10 samples are composed of partially dissolved zircon and basaltic glass with a linear interface between the zircon crystal and the final glass (Fig. 1). At the interface between these phases, profiles of $\mathrm{Zr}$ concentrations have been obtained for the Z1 sample as described above and illustrated in Figure 3.

$\mathrm{Z} 2$ and $\mathrm{Z3}$ samples obtained at $0.1 \mathrm{MPa}$ are made of partially and incongruently dissolved zircon overgrown by baddeleyite micro-crystals associated with the zone of $\mathrm{SiO}_{2}$-rich glass (Fig. 1). Z4 sample contains optically homogeneous basaltic glass, whereas chemical heterogeneity likely due to "vortex"-type convective mixing is of note on the BSE image in the lower part of the capsule, suggesting congruent dissolution of zircon followed by convective mixing of Zr-rich and Zr-poor melts.

In experiments $\mathrm{Z6}$ and $\mathrm{Z7}$, zircon in contact with haplobasaltic melt at $0.7 \mathrm{GPa}$ transformed to a system characterized by partial overgrowths of baddeleyite micro-crystals associated with $\mathrm{SiO}_{2}$-rich glass (Fig. 1).

A summary of the phase relations associated with zircon dissolution at 1250 to $1300{ }^{\circ} \mathrm{C}$ in (haplo-) basaltic melts (Fig. 4) shows that at $0.1 \mathrm{MPa}$, zircon dissolves incongruently to form baddeleyite $\left(\mathrm{ZrO}_{2}\right)$ and a $\mathrm{SiO}_{2}$-rich melt. Baddeleyite is also formed at $0.7 \mathrm{GPa}$ in the synthetic haplobasaltic (low $a_{\mathrm{SiO}_{2}}$ ) melt, but no baddeleyite precipitation is observed in the pressure range 0.2 to $0.7 \mathrm{GPa}$ in natural terrestrial tholeiitic basalt melt. The favorable experiment $Z 1$ has been used to extract the diffusion coefficient of $\mathrm{Zr}$, as described above, providing a value of $D_{\mathrm{Zr}}=2.87 \mathrm{E}-08 \mathrm{~cm}^{2} / \mathrm{s}$ at $1300{ }^{\circ} \mathrm{C}$ and $0.5 \mathrm{GPa}$ (Supplementary Materials $\left.{ }^{1}\right)$. For the question of the interface concentration of $\mathrm{Zr}$, zircon solubility is higher at $0.2 \mathrm{GPa}$ pressure (Z10 run, Table 1) compared to that at $0.5 \mathrm{GPa}$ (Z1 run), suggesting possible stabilization of zircon at high pressures. For modeling purposes, a value of $20840 \pm 104 \mathrm{ppm} \mathrm{Zr}$ was used (corresponding to zircon solubility in MORB melt at $0.5 \mathrm{GPa}$ and $1300^{\circ} \mathrm{C}$ ), and combined with the initial $\mathrm{Zr}$ concentration of $94.3 \mathrm{ppm}$ measured in the starting MORB glass (Borisova et al. 2020).

\section{Discussion}

\section{Zircon vs. baddeleyite stability during dissolution}

In general terms the relative stability of zircon and baddeleyite in terrestrial and extraterrestrial systems can be rationalized in terms of the silica activity of the silicate melt associated with the reaction: 


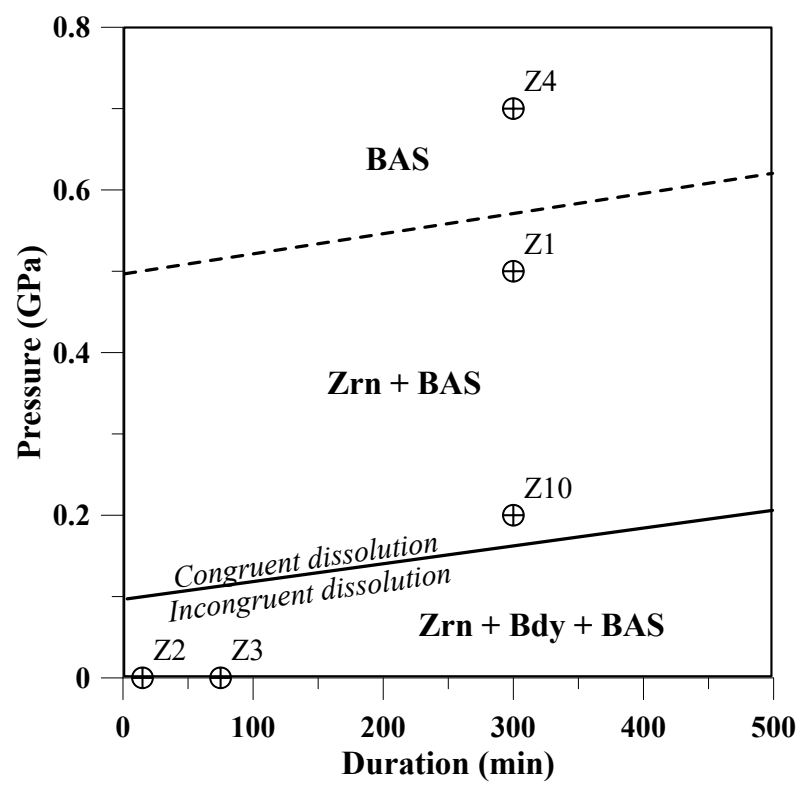

Figure 4. Pressure vs. run duration diagram of the composition of volatile-poor experimental samples after the runs on Mud Tank zircon-natural MORB-type basaltic melt pairs vs. the run duration. The experiments at 1250 to $1300^{\circ} \mathrm{C}$ used different pressure-loading techniques. BAS $=$ homogeneous basaltic glass; $\mathrm{Zrn}+\mathrm{BAS}=$ zircon with the reacted basaltic glass; Zrn + Bdy + BAS = zircon, baddeleyite with associated $\mathrm{SiO}_{2}$-rich glass and the reactional basaltic glass as the result of the reaction.

$$
\mathrm{ZrSiO}_{4}{ }^{\mathrm{Znn}}=\mathrm{ZrO}_{2}{ }^{\mathrm{Bdy}}+\mathrm{SiO}_{2}{ }^{\mathrm{L}}
$$

where Zrn is zircon, Bdy is baddeleyite, and L is silicate melt. Equation 1 implies that melts of higher silica activity will favor zircon stability, consistent with the fact that zircon prefers to crystallize in felsic, intermediate, and silica-saturated (high $a_{\mathrm{SiO}_{2}}$ ), rather than mafic and ultramafic systems (low $\left.a_{\mathrm{SiO}_{2}}\right)$. Indeed, Equation 1 predicts baddeleyite stability in low- $a_{\mathrm{SiO}_{2}}$ systems, such as ultramafic (e.g., carbonatite, kimberlite) and mafic (haplobasaltic) systems. For example, Gervasoni et al. (2017) investigated the system of zircon in low- $a_{\mathrm{SiO}_{2}}$ carbonatite melt at $0.7 \mathrm{GPa}$ and these authors described the stability of baddeleyite and incongruent dissolution of zircon crystals with formation of corona of baddeleyite. In contrast, no baddeleyite crystallization was observed by Shao et al. (2018) in a synthetic basalt system at pressures $0.5-1.5$ $\mathrm{GPa}$, implying baddeleyite stability only at lower pressures $(<0.5$ $\mathrm{GPa}$ ) in their basaltic systems. The observed effect of pressure on the relative stability of zircon and baddeleyite is consistent with the fact that increasing pressure tends to increase silica activity of mafic silicate melts, as illustrated by the displacement of the olivine-orthopyroxene cotectic. In any case, decompression will favor incongruent rather than congruent dissolution. We also note that comparison of Z2 and Z3 samples from the same time series experiments implies an approximately constant rate of baddeleyite rim formation of $0.9 \pm 0.2 \mu \mathrm{m} / \mathrm{min}$ at constant temperature, pressure, and water contents. This rate may be used as a kinetic indicator to calculate approximate timescales of the zircon megacryst transport to the surface.
Comparison of runs $\mathrm{Z} 6$ and $\mathrm{Z7}$ suggests that hydrous conditions (Table 1) favor congruent dissolution. Taken at face value, this would suggest that degassing leads to a tendency for incongruent dissolution, but we note that addition of water is generally accepted to decrease silica activity, a discrepancy that requires more study.

\section{Zr diffusivity and zircon solubility in silicate melts}

Most existing models considering zircon solubility and dissolution are based on felsic and intermediate and synthetic systems (zircon in felsic and intermediate silicate liquids, e.g., Harrison and Watson 1983; Boehnke et al. 2013; Zhang and Xu 2016; and references therein). In those cases, zircon is apparently less soluble and stable compared to the natural mafic and ultramafic systems. The main factors controlling solubility of zircon in silicate melts are temperature and the melt composition expressed in terms of ratio of nonbridging $\mathrm{O}$ atoms per tetrahedrally coordinated cations $(\mathrm{NBO} / \mathrm{T})$, which is a simple measure of silicate melt structure based on the ratio between network formers and network modifiers. For example, the factors such as $\mathrm{M}\{[(\mathrm{Na}+\mathrm{K}+2 \cdot \mathrm{Ca}) /(\mathrm{Al} \cdot \mathrm{Si})]$ (all in cation ratio $)\}, \mathrm{G}$ (where numerator $\left(3 \cdot \mathrm{Al}_{2} \mathrm{O}_{3}+\mathrm{SiO}_{2}\right)$ represents the network formers, while the denominator $\left(\mathrm{Na}_{2} \mathrm{O}+\mathrm{K}_{2} \mathrm{O}+\mathrm{CaO}+\mathrm{MgO}+\mathrm{FeO}\right)$ represent the network modifiers of the melt) or $\mathrm{B}$ expressed in oxide mole fractions in the melts $\left[0.14\left(\mathrm{X}_{\mathrm{TiO}_{2}} / \mathrm{X}_{\mathrm{SiO}_{2}}\right)+1.3\left(\mathrm{X}_{\mathrm{CaO}} /\right.\right.$ $\left.\mathrm{X}_{\mathrm{SiO}_{2}}\right)+1.5\left(\mathrm{X}_{\mathrm{Na}_{2} \mathrm{O}} / \mathrm{X}_{\mathrm{SiO}_{2}}\right)-4.5\left(\mathrm{X}_{\mathrm{K}_{2} \mathrm{O}} / \mathrm{X}_{\mathrm{SiO}_{2}}\right)-2.7\left(\mathrm{X}_{\mathrm{Al}_{2} \mathrm{O}_{3}} / \mathrm{X}_{\mathrm{SiO}_{2}}\right)^{2}+$ $\left.\left(\mathrm{X}_{\mathrm{MgO}} / \mathrm{X}_{\mathrm{SiO}_{2}}\right)^{2}-3.7\left(\mathrm{X}_{\mathrm{CaO}} / \mathrm{X}_{\mathrm{SiO}_{2}}\right)^{2}+75\left(\mathrm{X}_{\mathrm{K}_{2} \mathrm{O}} / \mathrm{X}_{\mathrm{SiO}_{2}}\right)^{2}\right]$ as well as the melt water contents have been proposed as factors controlling solubility of zircon in silicate melts (e.g., Harrison and Watson 1983; Gervasoni et al. 2016, 2017; Borisov and Aranovich 2019 and references therein). It is expected that the synthetic (Fe- and Ti-absent) and natural Fe- and Ti-containing basaltic melts would not be similar in respect to zircon solubility. Our natural basaltic liquid ( $8.2 \mathrm{wt} \%$ of $\mathrm{MgO}, \mathrm{M}=3.3 ; \mathrm{G}=2.5, \mathrm{~B}=0.15$ ) provides a theoretical zircon solubility of $23078 \mathrm{ppm}$ (or $2.3 \mathrm{wt} \%$ of $\mathrm{Zr}$ ) according to model of Borisov and Aranovich (2019), which is in a very good accordance with the experimentally measured solubility of $20840 \pm 104 \mathrm{ppm}$. The theoretical solubility of zircon in MORB melts is thus comparable to experimental ones (2.2-3.6 wt\% of Zr) obtained by Boehnke et al. (2013) for basaltic liquids at $1225^{\circ} \mathrm{C}$ and $1 \mathrm{GPa}$. The factors such as $\mathrm{M}, \mathrm{G}$, and $\mathrm{B}$ are indicators of zircon solubility in silicate melts but may be also used for prediction of $\mathrm{Zr}$ diffusivity, although the most efficient factor controlling the elemental diffusivity in silicate melts besides temperature remains the melt viscosity controlled primarily by the melt $\mathrm{SiO}_{2}$ content (e.g., Mungall 2002).

To predict zircon survival in natural basaltic systems, the diffusion coefficient of zirconium has been estimated based on the $\mathrm{Z} 1$ experiment, as described above (Fig. 3). Using the zirconium diffusion coefficient derived in this way $\left(2.87 \mathrm{E}-08 \mathrm{~cm}^{2} / \mathrm{s}\right)$ and the kinetic model of Bindeman and Melnik (2016), it is predicted that a sphere of zircon $100 \mu \mathrm{m}$ in diameter will survive for $\sim 10 \mathrm{~h}$, a sphere of $50 \mu \mathrm{m}$ diameter for $\sim 3 \mathrm{~h}$ and a grain $10 \mu \mathrm{m}$ in diameter for only $\sim 10 \mathrm{~min}$. At the other extreme, the dissolution of a $1 \mathrm{~cm}$ crystal such as Mud Tank zircon, would require $\sim 96000 \mathrm{~h}(\sim 11 \mathrm{yr})$.

However, before reaching firm conclusions concerning the timescales of zircon dissolution, we note that literature data on $\mathrm{Zr}$ diffusion in synthetic melts (Fig. 5) vary over more than 5 orders 
of magnitude. Despite this diversity, Zhang and Xu (2016) have proposed a predictive model of $\mathrm{Zr}$ diffusivity as a function of the melt composition and water contents (but not taking into account halogen and $\mathrm{CO}_{2}$ contents). Our experimentally measured $\mathrm{Zr}$ diffusivity has been compared to Equation 9 of Zhang and $\mathrm{Xu}$ (2016) for our studied melt composition and experimental conditions (Supplementary Material ${ }^{1}$ ) as well as to the measured and calculated values from the other experimental works (Fig. 6). We note that our measured $\mathrm{Zr}$ diffusivity in natural tholeiitic basalt is comparable to those of synthetic haplobasalt (LaTourrette et al. 1996) and synthetic basalt (Holycross and Watson 2016), close to the line 1:1 on Figure 6, suggesting a good fit between the experiments for dry basaltic systems and the theoretical model for the basaltic systems. Additionally, other experimental data (except for those of Koepke and Behrens 2001) broadly spread along the line $1: 1$. We thus conclude that the model of Zhang and $\mathrm{Xu}$ (2016) may be used to predict $\mathrm{Zr}$ diffusivity in volatile-poor natural basaltic melts such as those studied here.

\section{IMPLICATIONS}

Our experimental data on zircon dissolution and solubility in a natural basaltic system shed light on the presence of zircon in terrestrial and extraterrestrial mafic to ultramafic magmas and rocks. First of all, we note that predicted survival times for zircon in mafic/ultramafic systems are very short compared to

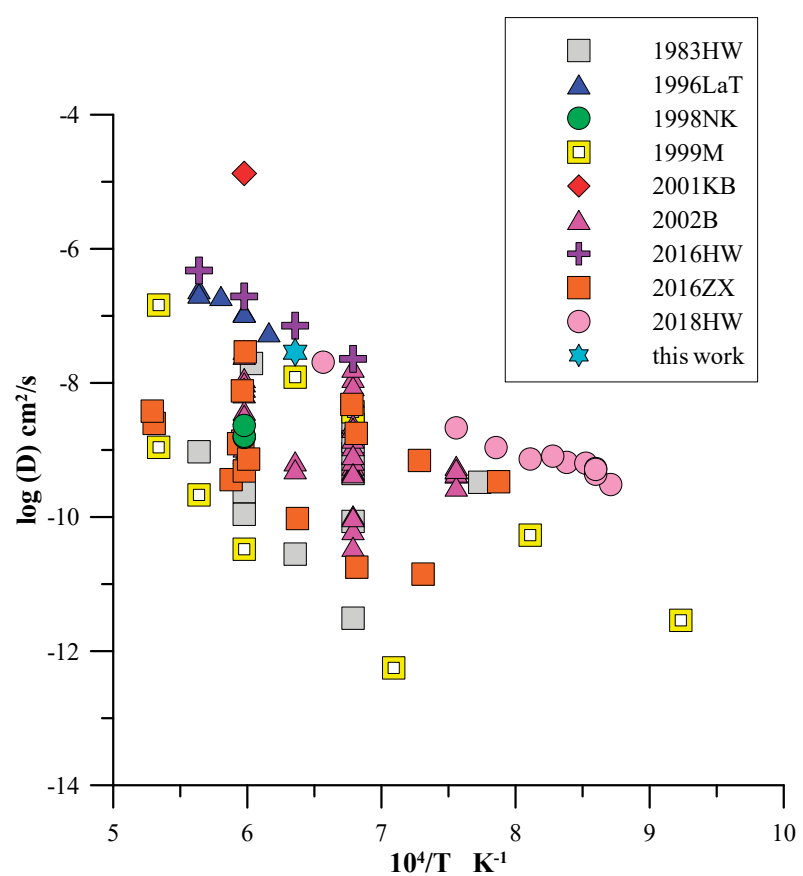

Figure 5. All available and new (this work) experimental data on $\mathrm{Zr}$ diffusivity (D) in dry and hydrous silicate melts [in $\log (\mathrm{D}), \mathrm{D}$ in $\mathrm{cm}^{2} / \mathrm{s}$ ] vs. temperature $\left(10000 / \mathrm{T}\right.$ in $\left.\mathrm{K}^{-1}\right)$. The (haplo-) basaltic systems are represented by data of $1996 \mathrm{LaT}=$ LaTourrette et al. 1996, 2016HW $=$ Holycross and Watson 2016, and this work. The other systems, such as $1983 \mathrm{HW}$ representing data of Harrison and Watson 1983, $1998 \mathrm{NK}=$ Nakamura and Kushiro 1998, 1999M = Mungall et al. 1999, 2001KB = Koepke and Behrens 2001, 2002B = Baker et al. 2002, 2016ZX = Zhang and $\mathrm{Xu} 2016,2018 \mathrm{HW}=$ Holycross and Watson 2018 are dry to hydrous intermediate to felsic systems. typical timescales for magma transfer from the mantle (e.g., $10^{-4}$ to $10^{2}$ years, as compiled by Turner and Costa 2007: Fig. 7). This suggests that most zircon megacrysts will be dissolved, even for the extreme case of $1 \mathrm{~cm}$ zircon crystals (such as Mud Tank) that only require $11 \mathrm{yr}$ to disappear.

To explain the presence of zircon in tholeiitic basaltic melts at upper mantle temperatures of $1300{ }^{\circ} \mathrm{C}, \mathrm{Zr}$ concentrations in melts have to reach 20000-30000 ppm (Table 1). Thus, zircon crystallization directly from basaltic melt with common $\mathrm{Zr}$ concentration of tens to hundreds of parts per million is virtually impossible. The presence of zircon in mafic and ultramafic rocks may thus be related to some other processes that led to $\mathrm{Zr}$ enrichment. Such processes include partial melting of hydrated peridotite (Borisova et al. 2017, 2020), felsic lithosphere (e.g., continental crust and oceanic plagiogranite) and/or the felsic crustal involvement/recycling or zircon sealing (Belousova et al. 2015; Bea et al. 2018, 2020).

Alternatively, formation mechanisms of zircon may be related to lower temperature processes that include high degree of fractional crystallization in closed systems (e.g., Borisov and Aranovich 2019), total zircon dissolution and reprecipitation (Bea et al. 2001) and/or a contribution of metasomatic Si-F-rich fluid (e.g., Louvel et al. 2013). It is also possible that the final differentiates of metasomatized mafic/ultramafic magmas in the mantle, with "special" peralkaline chemistry, and involving fluorine can lead to "pegmatitic" zircon megacryst growth. Zircon solubility strongly depends on temperature, thus relatively

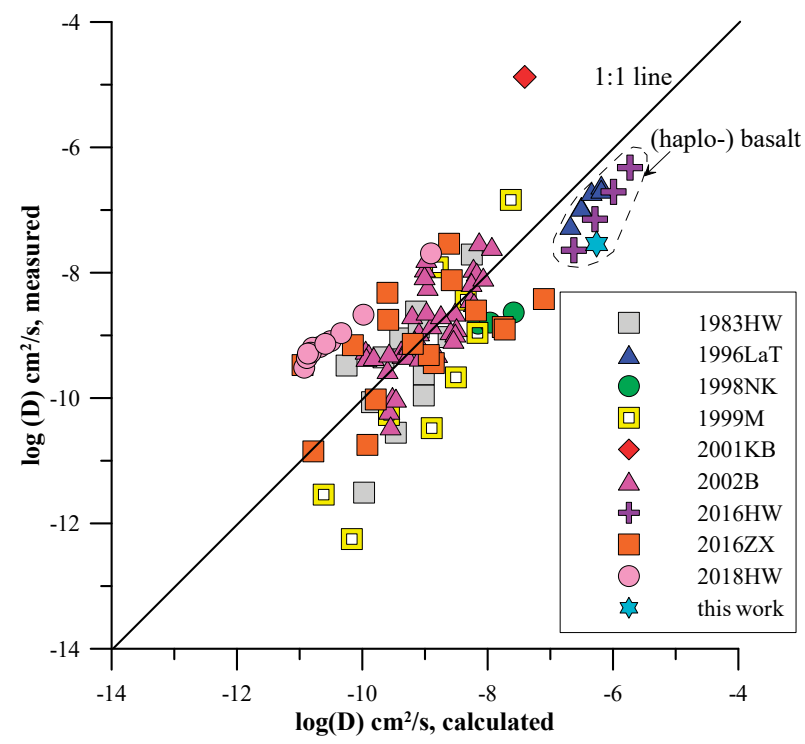

Figure 6. All available and new data on the measured $\mathrm{Zr}$ diffusivity $\left[\log (\mathrm{D}), \mathrm{D}\right.$ in $\left.\mathrm{cm}^{2} / \mathrm{s}\right]$ in dry and hydrous silicate melts vs. calculated $\mathrm{Zr}$ diffusivity $\left[\log (\mathrm{D}), \mathrm{D}\right.$ in $\mathrm{cm}^{2} / \mathrm{s}$ ] after Zhang and $\mathrm{Xu}$ (2016) (calculated on hydrous basis). The (haplo-) basaltic systems are represented by data of $1996 \mathrm{LaT}=$ LaTourrette et al. 1996, 2016HW = Holycross and Watson 2016, and this work. The other systems, such as 1983HW representing data of Harrison and Watson 1983, 1998NK = Nakamura and Kushiro 1998, 1999M = Mungall et al. 1999, 2001 KB = Koepke and Behrens 2001, 2002B = Baker et al. 2002, 2016ZX $=$ Zhang and $\mathrm{Xu} 2016,2018 \mathrm{HW}=$ Holycross and Watson 2018 are dry to hydrous intermediate to felsic systems. 


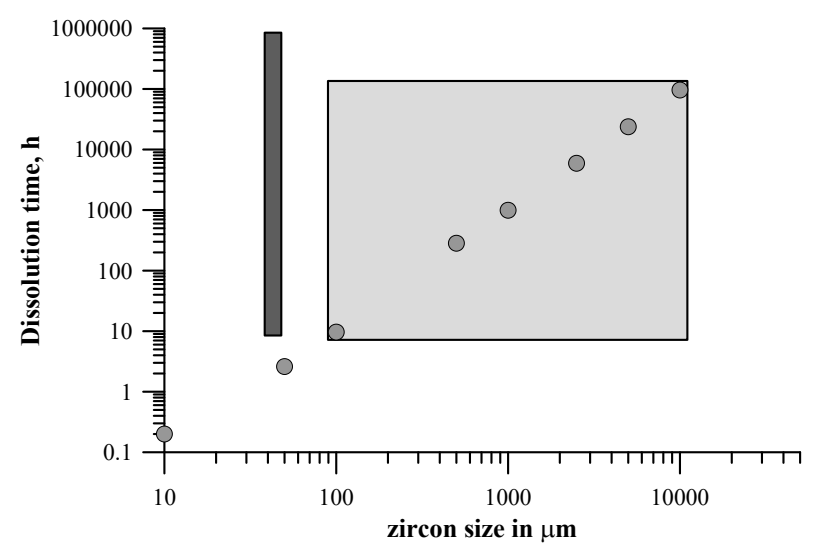

Figure 7. The calculated time of zircon dissolution in tholeiitic basaltic melt at $1300^{\circ} \mathrm{C}$ according to the kinetic model of Bindeman and Melnik (2016) vs. zircon size (in micrometers). The shaded light gray field corresponds to the dissolution timescales from hours to years according to the typical sizes of zircon crystals and megacrysts in carbonatites and kimberlites. The dark gray bar is a range of typical timescales for the magma transfer from mantle (from $10^{-4}$ to $10^{2}$ years) according to Turner and Costa (2007), suggesting high percentage of the zircon crystals and megacrysts to be dissolved upon their transport to the surface.

cold lithospheric roots with temperatures $<1000{ }^{\circ} \mathrm{C}$ are possible environments for these processes.

The presence of zircon in intercumulus residual melt from layered (ultra-) mafic intrusions and/or shallow magma chambers provides evidence in favor of these scenarios (Fig. 8). For example, according to the study of Bychkova et al. (2019a, 2019b), closed-system fractional crystallization with convective mixing of magma in the chamber is capable of explaining zircon grains within the (ultra-)mafic layered series and the leucocratic granophyre rocks of the 1.8 Ga layered Kivakka intrusion (Karelia, Russia). We also note that zircon is present in the granophyric Sandwich horizon of $56 \mathrm{Ma}$ Skaergaard intrusion of Eastern Greenland, as well as ultramafic pegmatitic segregations of its cumulus pile (Bindeman et al. 2008; Wotzlaw et al. 2012).

These examples of mafic/ultramafic layered intrusions indicate that similar interstitial processes may take place in the mantle, perhaps helped by metasomatizing fluids (mantle metasomatism) and/or creation of localized felsic systems by partial melting or induced by fluid-rock interaction. For example, isotopically homogeneous megacrysts such as Mud Tank zircon (Valley 2003; Gain et al. 2019) might be associated with such metasomatism involving fluids rather than incompatible elementrich silicate melts. These zircon crystals may have been formed at mantle conditions from some type of ultramafic melts/fluids. However, the presence of these zircon megacrysts in carbonatite rocks is in contradiction to the recent experimental data by Gervasoni et al. $(2016,2017)$, suggesting that zircon is not stable in a low-silica carbonatite melt and that zircon may not be a primary mineral in low-silica (carbonatite) melts. Kinetic constraints (i.e., slow reaction rates and incongruent dissolution) may help to preserve metastable zircon, but this idea cannot be tested in the absence of experimental data concerning zircon dissolution/ precipitation rates and mechanisms at relevant conditions.

Reconstructing the detailed formation history of Mud Tank

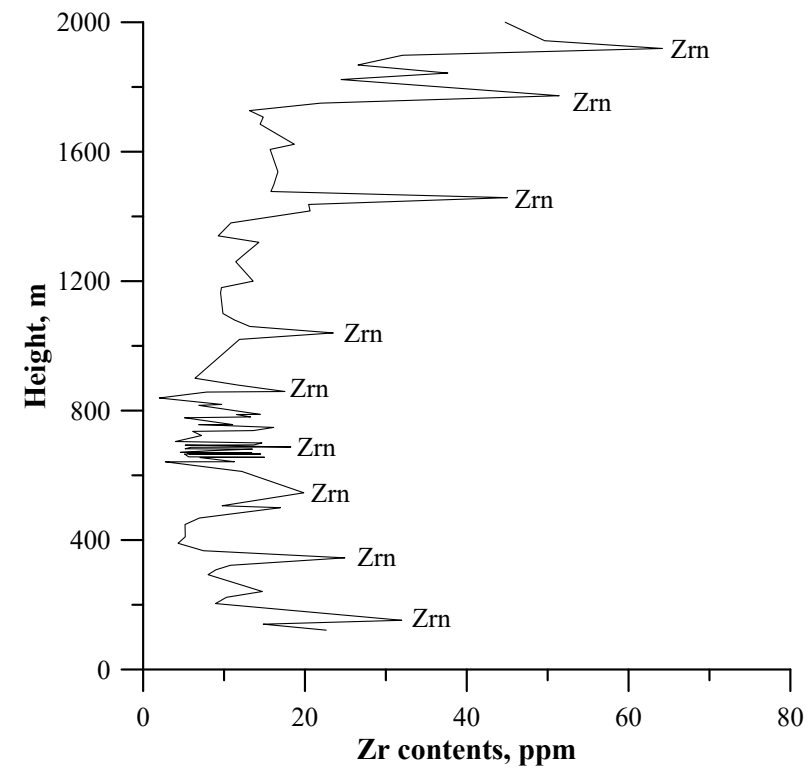

Figure 8. H, $m$ is height in meters vs. $\mathrm{Zr}$ in parts per million contents in rocks of the Kivakka mafic-ultramafic layered intrusion, Northern Karelia, Russia. "Zrn” indicates zircon-bearing horizons of (ultra-) mafic rocks. The data are after Bychkova et al. (2019a, 2019b). The main mechanism of zircon crystallization in (ultra-) mafic systems is residual intercumulus melt crystallization.

zircon is beyond the scope of this contribution, but it was clearly not in equilibrium with mafic-ultramafic melts at magmatic temperatures. On the other hand, Mud Tank zircon has a strong mantle signature of $\mathrm{Hf}$ isotope composition (the average $\varepsilon_{\mathrm{Hf}}$ at 731 Ma is +7.0 based on recent data of Gain et al. 2019 and CHUR ${ }^{176} \mathrm{Hf} /{ }^{177} \mathrm{Hf}_{\mathrm{o}}=0.282785$ and ${ }^{176} \mathrm{Lu} /{ }^{177} \mathrm{Hf}_{\mathrm{o}}=0.0336$ of Vervoort 2014), despite elemental and isotopic diffusion that are extremely sluggish (Cherniak 2010) and unable to lead to internal homogenization in the presence of melts or fluid (e.g., Bea et al. 2018; Bindeman et al. 2018). Thus, it appears likely that these zircon megacrysts are related to mantle metasomatism with little or no crustal contribution, in agreement with conclusions of Currie et al. (1992) concerning the origin of the Mud Tank Carbonatite complex as a whole and a detailed geochemical study of Mud Tank zircon crystals and the zircon-hosted inclusions (Gain et al. 2019).

It should be noted also that the primitive mantle-normalized pattern of the primary carbonatite melts has no $\mathrm{Zr}$ and $\mathrm{Hf}$ anomalies (Walter et al. 2008) compared to the well-known strong $\mathrm{Zr}$ and $\mathrm{Hf}$ depletions in composition of the carbonatite rock and glasses from the oceanic settings (e.g., Hauri et al. 1993). This fact implies that a deep magmatic process (e.g., liquid immiscibility or/and fractional crystallization of a mineral phase) might have been responsible for the formation of the strong negative $\mathrm{Zr}$ and $\mathrm{Hf}$ anomalies at high pressures (perhaps, at $\sim 9 \mathrm{GPa}$ ), due to differentiation of the primary carbonatite melts. Perhaps, zircon, reidite or another high-pressure $\mathrm{Zr}$-rich mineral phase (e.g., Timms et al. 2017) might be such phase responsible for the $\mathrm{Zr}$ and $\mathrm{Hf}$ depletions and might be formed from the carbonatite melts at deep asthenospheric conditions (>1.0 GPa). However, zircon stability and solubility have never been investigated experimentally yet at these high- to ultrahigh-pressure conditions. 


\section{CONCLUDING REMARKS}

(1) Our data confirm high solubility of zircon in basalt of 20000-30000 ppm Zr, and establish very fast congruent dissolution of zircon in natural basaltic melt at pressures of 0.2 to $0.7 \mathrm{GPa}$ and a temperature of $1300^{\circ} \mathrm{C}$.

(2) We have calculated timescales of zircon survival in natural mafic liquids of tholeitic basalt composition $(\mathrm{M}=3.3 ; \mathrm{G}=2.5$; $\mathrm{B}=0.15$ ). For example, spherical zircon of $1 \mathrm{~cm}$ in diameter will be completely dissolved at $1300^{\circ} \mathrm{C}$ and $0.5 \mathrm{GPa}$ in tholeiitic basaltic liquid in $\sim 11$ years, $100 \mu \mathrm{m}$ zircon in $\sim 10 \mathrm{~h}$, a zircon sphere of $50 \mu \mathrm{m}$ in $\sim 3 \mathrm{~h}$ and a $10 \mu \mathrm{m}$ sphere in $\sim 10 \mathrm{~min}$.

(3) Zircon in natural ultramafic (carbonatite) and mafic (haplobasaltic) melts dissolves incongruently resulting in formation of a rim of baddeleyite microcrystals in association with $\mathrm{SiO}_{2}$-rich melt. Incongruent dissolution of zircon at low pressures $(<0.2 \mathrm{GPa}$ for natural basaltic melts) hampers the bulk zircon dissolution because of the formation of a baddeleyite halo associated with viscous $\mathrm{SiO}_{2}-$ rich melt. The estimated rate of rim formation $(\sim 0.9 \mu \mathrm{m} / \mathrm{min})$ may be used as a kinetic indicator to calculate approximate timescales of the zircon megacryst transport to the surface.

(4) The new experimental data suggest fast zircon transfer to the surface during magma generation and transport lasting hours to days. Formation and survival of zircon in the lithosphere and asthenosphere, requires special conditions involving fluids and intercumulus melts or/and fluids tracking geodynamic and geochemical conditions of the terrestrial mantle-crust system.

\section{ACKNOWLEDGMENTS}

Authors thank Editor Bruce Watson, reviewer John M. Hanchar and one anonymous reviewer for the important suggestions on the first version of this paper. Oscar Laurent is thanked for discussion on the Mud Tank zircon origin.

\section{FUNDING}

O.E.M. and I.N.B. acknowledge financial support from RFFI grant no. 1801-00352. This work was supported by the Institut Carnot ISIFoR, Deutsche Forschungsgemeinschaft (DFG) German Research Foundation, the University of Bayreuth, and AST Planets of the Observatoire Midi-Pyrénées (A.Y. Borisova, M.J.T., and N.R.Z).This study was fulfilled under the Research Program AAAAA18-118020590148-3 of the Korzhinskii Institute of Experimental Mineralogy RAS (O.G.S.). Required thermodynamic calculations were supported by the RSF grant 19-17-00200 (A.Y. Bychkov). This work was supported by RNF grant \#19-17-00241 (I.N.B.).

\section{REFERENCES CITED}

Anfilogov, V.N., Krasnobaev, A.A., Ryzhkov, V.M., Kabanova, L.Y., Valizer, P.M., and Blinov, I.A. (2015) Stability of zircon in dunite at $1400-1550^{\circ} \mathrm{C}$. Doklady Earth Sciences, 464, 963-966.

Ashwal, L.D., Wiedenbeck, M., and Torsvik, T.H. (2017) Archaean zircons in Miocene oceanic hotspot rocks establish ancient continental crust beneath Mauritius. Nature Communications, 8, 14086.

Ballhaus, C., Berry, R.F., and Green, D.H. (1991) High pressure experimental calibration of the olivine-orthopyroxene-spinel oxygen geobarometer: implications for the oxidation state of the upper mantle. Contributions to Mineralogy and Petrology, 107, 27-40.

Baker, D.R., and Watson, E.B. (1988) Diffusion of major and trace elements in compositionally complex Cl- and F-bearing silicate melts. Journal of NonCrystalline Solids, 102, 62-67.

Baker, D.R., Conte, A.M., Freda, C., and Ottolini, L. (2002) The effect of halogens on $\mathrm{Zr}$ diffusion and zircon dissolution in hydrous metaluminous granitic melts. Contributions to Mineralogy and Petrology, 142, 666-678. DOI: 10.1007/ s00410-001-0328-3.

Bea, F., Fershtater, G.B., Montero, P., Whitehouse, M., Levin, V.Y., Scarrow, J.W., Autreim, H., and Pushkariev, E.V. (2001) Recycling of continental crust into the mantle as revealed by Kytlym dunite zircons, Ural Mts, Russia. Terra Nova, 13, 407-412.

Bea, F., Montero, P., and Molina-Palma, J.F. (2018) Experimental evidence for the preservation of $\mathrm{U}-\mathrm{Pb}$ isotope ratios in mantle-recycled crustal zircon grains.
Scientific Reports, 8, 12904

Bea, F., Bortnikov, N., Montero, P., Zinger, T., Sharkov, E., Silantyev, S., Skolotnev, S., Trukhalev, A., and Molina-Palma, J.F. (2020) Zircon xenocryst evidence for crustal recycling at the Mid-Atlantic Ridge. Lithos, 354-355, 105361.

Behrens, H., and Hahn, M. (2009) Trace element diffusion and viscous flow in potassium-rich trachytic and phonolitic melts. Chemical Geology, 259, 63-77.

Bellucci, J.J., Nemchin, A.A., Grange, M., Robinson, K.L., Collins, G., Whitehouse, M.J., Snape, J.F. Norman, M.D., and Kring, D.A. (2019) Terrestriallike zircon in a clast from an Apollo 14 breccia. Earth and Planetary Science Letters, 510, 173-185.

Belousova, E.A., Griffin, W.L., O'Reilly, S.Y., and Fisher, N.I. (2002) Igneous zircon: trace element composition as an indicator of source rock type. Contributions to Mineralogy and Petrology, 143, 602-622. DOI: 10.1007/ s00410-002-0364-7.

Belousova, E.A., González-Jiménez, J.M., Graham, I.T., Griffin, W.L., O'Reilly, S.Y., Pearson, N.J., Martin, L., Craven, S., and Talavera, C. (2015) The enigma of crustal zircons in upper mantle rocks: clues from the Tumut ophiolite, SE Australia. Geology, 43, 119-122.

Bindeman, I.N., and Melnik, O.E. (2016) Zircon survival, rebirth and recycling during crustal melting, magma crystallization, and mixing based on numerical modelling. Journal of Petrology, DOI: 10.1093/petrology/egw013.

Bindeman, I.N., Brooks, C.K., McBirney, A.R., and Taylor, H.P. (2008) The low$\delta^{18} \mathrm{O}$ late-stage ferrodiorite magmas in the Skaergaard Intrusion: Result of liquid immiscibility, thermal metamorphism, or meteoric water incorporation into magma? Journal of Geology, 116, 571-586.

Bindeman, I.N., Kamenetsky, V., Palandri, J., and Vennemann, T. (2012) Hydrogen and oxygen isotope behavior during variable degrees of upper mantle melting: example from the basaltic glasses from Macquarie Island. Chemical Geology, 310-311, 126-136.

Bindeman, I.N., Schmitt, A.K., Lundstrom, C.C., and Hervig, R.L. (2018) Stability of zircon and its isotopic ratios in high-temperature fluids: Long-term (4 months) isotope exchange experiment at $850^{\circ} \mathrm{C}$ and $50 \mathrm{MPa}$. Frontiers in Earth Sciences, 6, 10.3389/feart.2018.00059.

Boehnke, P. Watson, E.B., Trail, D., Harrison, T.M., and Schmitt, A.K. (2013) Zircon saturation re-revisited. Chemical Geology, 351, 324.

Borisov, A., and Aranovich, L. (2019) Zircon solubility in silicate melts: New experiments and probability of zircon crystallization in deeply evolved basic melts. Chemical Geology, 510, 103-112.

Borisova, A.Y., Zagrtdenov, N.R., Toplis, M.J., Bohrson, W.A, Nedelec, A., Safonov, O.G., Pokrovski, G.S., Ceuleneer, G., Melnik, O.E., Bychkov, A.Y., and others. (2017) Making Earth's continental crust from serpentinite and basalt. Goldschmidt 13-18 August 2017, Paris, France.

Borisova, A.Y., Zagrtdenov, N.R., Toplis, M.J., Donovan, J.J., Llovet, X., Asimov, P.D., de Parseval, P., and Gouy, S. (2018) Secondary fluorescence effects in microbeam analysis and their impacts on geospeedometry and geothermometry. Chemical Geology, 490, 22-29.

Borisova, A.Y., Zagrtdenov, N.R., Toplis, M.J., Ceuleneer, G., Safonov, O.G., Shcheka, S., and Bychkov, A.Y. (2020) Hydrated peridotite-basaltic melt interaction Part II: Fast assimilation of serpentinized mantle by basaltic magma. Frontiers in Earth Science, DOI: 10.3389/feart.2020.00084.

Burnham, A.D., and Berry, A.J. (2012) An experimental study of trace element partitioning between zircon and melt as a function of oxygen fugacity. Geochimica et Cosmochimica Acta, 95, 196-212.

Bychkova, Y.V., Mikliaeva, E.P., Koptev-Dvornikov, E.V., Borisova, A.Y., Bychkov, A.Y., and Minervina, E.A. (2019a) Proterozoic Kivakka layered maficultramafic intrusion, Northern Karelia, Russia: Implications for the origin of granophyres of the upper boundary group. Precambrian Research, 331, 105381.

Bychkova, Y.V., Bychkov, D.A., Minervina, E.A., Ivlev, B.A., Tskhovrebova, A.R., Kas'yan, A.K., and Miklyaeva, E.P. (2019b) Tendencies of REE distribution in the Kivakka olivinite-gabbro-norite layered intrusion (Northern Karelia). Geochemistry International, 57(2), 151-169.

Cherniak, D.J. (2010) Diffusion in accessory minerals: zircon, titanite, apatite, monazite and xenotime. Reviews in Mineralogy and Geochemistry, 72, 827-869.

Crohn, P.W., and Moore, D.H. (1984) The Mud Tank Carbonatite, Strangways Range, central Australia. Journal of Australian Geology \& Geophysics, 9, $13-18$.

Currie, K.L., Knutson, J., and Temby, P.A. (1992) The Mud Tank carbonatite complex, central Australia - an example of metasomatism at mid-crustal levels. Contributions to Mineralogy and Petrology, 109, 326-339.

Dickinson, J.E., and Hess, P.C. (1982) Zircon saturation in lunar basalts and granites. Earth and Planetary Science Letters, 57, 336-344.

Ellison, A.J., and Hess, P.C. (1986) Solution behavior of +4 cations in high silica melts: petrologic and geochemical implications. Contributions to Mineralogy and Petrology, 94, 343-351.

Gain, S.E.M., Gréau, Y., Henry, H., Belousova, E., Dainis, I., Griffin, W.L., and O'Reilly, S.Y. (2019) Mud tank zircon: Long-term evaluation of a reference material for $\mathrm{U}-\mathrm{Pb}$ dating, Hf-isotope analysis and trace element analysis. Geostandards and Geoanalytical Research, 43, 339-354.

Geisler, T., Schaltegger, U., and Tomaschek, F. (2007) Re-equilibration of zircon 
in aqueous fluids and melts. Elements, 3, 43-50.

Gervasoni, F., Klemme, S., Rocha-Júnior, E.R.V., and Berndt, J. (2016) Zircon saturation in silicate melts: a new and improved model for aluminous and alkaline melts. Contributions to Mineralogy and Petrology, 171, 21. DOI: 10.1007/s00410-016-1227-y.

Gervasoni, F., Klemme, S., Rohrbach, A., Grützner, T., and Berndt, J. (2017) Experimental constraints on the stability of baddeleyite and zircon in carbonate- and silicate-carbonate melts. American Mineralogist, 102, 860-866.

González-Jiménez, J.M., Marchesi, C., Griffin, W.L., Gervilla, F., Belousova, E.A., Garrido, C.J., and Martin, L. (2017) Zircon recycling and crystallization during formation of chromite- and $\mathrm{Ni}$-arsenide ores in the subcontinental lithospheric mantle (Serranía de Ronda, Spain). Ore Geology Reviews, 90, 193-209. DOI: 10.1016/j.oregeorev.2017.02.012.

Hauri, E.H., Shimizu, N., Dieu, J.J., and Hart, S.R. (1993) Evidence for hotspotrelated carbonatite metasomatism in the oceanic upper mantle. Nature, 365, 221-226.

Harrison, T.M., and Watson, E.B. (1983) Kinetics of zircon dissolution and zirconium diffusion in granitic melts of variable water content. Contributions to Mineralogy and Petrology, 84, 66-72.

Holycross, M.E., and Watson, E.B. (2016) Diffusive fractionation of trace elements in basaltic melt. Contributions to Mineralogy and Petrology, 171, 1-15.

- (2018) Trace element diffusion and kinetic fractionation in wet rhyolitic melt. Geochimica et Cosmochimica Acta, 232, 14-29.

Humayun, M., Nemchin, A., Zanda, B., Hewins, R.H., Grange, M., Kennedy, A., Lorand, J.P., Göpel, C., Fieni, C., Pont, S., and Deldicque, D. (2013) Origin and age of the earliest Martian crust from meteorite NWA 7533. Nature, 503, $513-516$.

Iizukaa, T. Yamaguchia, T., Hibiyaa, Y., and Amelin, Y. (2015) Meteorite zircon constraints on the bulk Lu-Hf isotope composition and early differentiation of the Earth. Proceedings of the National Academy of Sciences, 112, 5331-5336, DOI: 10.1073 /pnas.1501658112.

Ireland, T.R., and Wlotzka, F. (1992) The oldest zircons in the solar system. Earth and Planetary Science Letters, 109, 1-10.

Jochum, K.P., Stoll, B., Herwig, K., Willbold, M., Hofmann, A.W., Amini, M., Aarburg, S., Abouchami, W., Hellebrand, E., Mocek, B., and others. (2006) MPI-DING reference glasses for in situ microanalysis: New reference values for element concentrations and isotope ratios. Geochemistry, Geophysics, Geosystems, 7/2. DOI: 10.1029/2005GC001060.

Kaczmarek, M.-A., Müntener, O., and Rubatto, D. (2008) Trace element chemistry and $\mathrm{U}-\mathrm{Pb}$ dating of zircons from oceanic gabbros and their relationship with whole rock composition (Lanzo, Italian Alps). Contributions to Mineralogy and Petrology, 155, 295-312. DOI: 10.1007/s00410-007-0243-3.

Koepke, J., and Behrens, H. (2001) Trace element diffusion in andesitic melts: An application of synchrotron X-ray fluorescence analysis. Geochimica et Cosmochimica Acta, 65, 1481-1498.

Kostitsyn, Yu.A., Belousova, E.A., Bortnikov, N.S., and Sharkov, E.V. (2009) Zircons in gabbroid from the axial zone of the mid atlantic ridge: $\mathrm{U}-\mathrm{Pb}$ age and ${ }^{176} \mathrm{Hf} /{ }^{177} \mathrm{Hf}$ ratio (Results of investigations by the laser ablation method). Doklady Earth Sciences, 429, 1305-1309.

Kostitsyn, Yu.A., Silant'ev, S.A., Belousova, E.A., Bortnikov, N.S., Krasnova, E.A., and Cannat, M. (2012) Time of the formation of the Ashadze hydrothermal field in the Mid Atlantic Ridge $\left(12^{\circ} 58^{\circ} \mathrm{N}\right)$ : Evidence from zircon study. Doklady Earth Sciences, 447, 1301-1305.

Kostitsyn, Yu.A., Belousova, E.A., Silant'ev, S.A., Bortnikov, N.S., and Anosova, M.O. (2015) Modern problems of geochemical and U-Pb geochronological studies of zircon in oceanic rocks. Geochemistry International, 53, 759-785.

LaTourrette, T., Wasserburg, G.J., and Fahey, A.J. (1996) Self diffusion of Mg, Ca, $\mathrm{Ba}, \mathrm{Nd}, \mathrm{Yb}, \mathrm{Ti}, \mathrm{Zr}$, and $\mathrm{U}$ in haplobasaltic melt. Geochimica et Cosmochimica Acta, 60, 1329-1340.

Louvel, M., Sanchez-Valle, C., Malfait, W.J., Testemale, D., and Hazemann, J-L. (2013) Zr complexation in high pressure fluids and silicate melts and implications for the mobilization of HFSE in subduction zones. Geochimica et Cosmochimica Acta, 104, 281-299.

Lundstrom, C.C. (2003) An experimental investigation of the diffusive infiltration of alkalis into partially molten peridotite: Implications for mantle melting processes. Geochemistry, Geophysics, Geosystems, 4(9), 8614, DOI:10.1029/2001GC000224.

Matjuschkin, V., Brooker, R.A., Tattitch, B., Blundy, J.D., and Stamper, C.C. (2015) Control and monitoring of oxygen fugacity in piston cylinder experiments. Contributions to Mineralogy and Petrology, 171, 66, DOI: 10.1007/ s00410-016-1274-4.
Mungall, J.E. (2002) Empirical models relating viscosity and tracer diffusion in magmatic silicate melts. Geochimica et Cosmochimica Acta, 66, 125-143.

Mungall, J.E., Dingwell, D.B., and Chaussidon, M. (1999) Chemical diffusivities of 18 trace elements in granitoid melts. Geochimica et Cosmochimica Acta, $63,2599-2610$.

Nakamura, E., and Kushiro, I. (1998) Trace element diffusion in jadeite and diopside melts at high pressures and its geochemical implication. Geochimica et Cosmochimica Acta, 62, 3151-3160.

Oliphant, T.E. (2006) Guide to NumPy, 261 p. Massachusetts Institute of Technology, U.S.A.

Rubatto, D., and Hermann, J. (2007) Experimental zircon/melt and zircon/garnet trace element partitioning and implications for the geochronology of crustal rocks. Chemical Geology, 241, 38-61.

Shao, T., Xia, Y., Ding, X., Cai, Y., and Song, M. (2018) Zircon saturation in terrestrial basaltic melts and its geologic implications. Solid Earth Sciences, 1-16. DOI: 10.1007/s11631-019-00384-4.

Schmitt, A.K., Danis, M., Aydar, E., Sen, E., Ulusoy, I., and Lovera, O.M. (2014) Identifying the volcanic eruption depicted in a Neolithic painting at Catalhöyük, Central Anatolia, Turkey. PLOS One, 9, e84711. DOI:10.1371/ journal.pone.0084711.

Sushchevskaya, N.M., Tsekhonya, T.I., Kononkova, N.N., Tcherkashov, G.A., Bogdanov, Y.A., and Belyatsky, B.V. (2000) Magmatism of Mona and Knipovich ridges from spreading zones of polar Atlantic Ocean. Russian Journal of Geosciences, 2, 243-267 (in Russian).

Timms, N.E., Erickson, T.M., Pearce, M.A., Cavosie, A.J., Schmieder, M., Tohver, E., Reddy, S.M., Zanetti, M.R., Nemchin, A.A., and Wittmann, A. (2017) A pressure-temperature phase diagram for zircon at extreme conditions. EarthScience Reviews, 165, 185-202.

Toplis, M.J., Dingwell, D.B., and Libourel, G. (1994) The effect of phosphorus on the iron redox ratio, viscosity, and density of an evolved ferro-basalt. Contributions to Mineralogy and Petrology, 117, 293-304.

Turner, S., and Costa, F. (2007) Measuring timescales of magmatic evolution. Elements, 3, 267-272.

Valley, J.W. (2003) Oxygen isotopes in zircon. Reviews in Mineralogy and Geochemistry, 53, 343-385. DOI: 10.2113/0530343.

Valley, J.W., Cavosie, A.J., Ushikubo, T., Reinhard, D.A., Lawrence, D.F., Larson, D.J., Clifton, P.H., Kelly, T.F., Wilde, S.A., Moser, D.E., and Spicuzza, M.J. (2014a) Hadean age for a post-magma-ocean zircon confirmed by atom-probe tomography. Nature Geoscience, 7, 219-223.

Valley, J.W., Spicuzza, M.J., and Ushikubo, T. (2014b) Correlated $\delta^{18} \mathrm{O}$ and [Ti] in lunar zircons: a terrestrial perspective for magma temperatures and water content on the Moon, Contributions to Mineralogy and Petrology, 167, 956.

Vervoort, J. (2014) Lu-Hf Dating: The Lu-Hf Isotope System. Encyclopedia of Scientific Dating Methods. Springer.

Walter, M.J., Bulanova, G.P., Armstrong, L.S., Keshav, S., Blundy, J.D., Gudfinnsson, G., Lord, O.T., Lennie, A.R., Clark, S.M., Smith, C.B., and Gobbo, L. (2008) Primary carbonatite melt from deeply subducted oceanic crust. Nature, $454,622-626$.

Watson, E.B. (1982) Basalt contamination by continental crust: Some experiments and models. Contributions to Mineralogy and Petrology, 80, 73-87.

Watson, E.B., Wark, D.A., and Thomas, J.B. (2006) Crystallization thermometers for zircon and rutile. Contributions to Mineralogy and Petrology, 151, 413-433.

Wotzlaw, J.F., Bindeman, I.N., Schaltegger, U., Brooks, C.K., and Naslund, H.R. (2012) High-resolution insights into episodes of crystallization, hydrothermal alteration and remelting in the Skaergaard intrusive complex, Earth and Planetary Science Letters, 355-356, 199-212.

Zhang, Y., and Xu, Z. (2016) Zircon saturation and Zr diffusion in rhyolitic melts, and zircon growth geospeedometer. American Mineralogist, 101, 1252-1267.

MANUSCRIPT ReCEIVED DeCEMBER 11, 2019

MANUSCRIPT ACCEPTED MAY 22, 2020

MANUSCRIPT HANDLED BY BRUCE WATSON

\section{Endnote:}

${ }^{1}$ Deposit item AM-20-117402, Data Set. Deposit items are free to all readers and found on the MSA website, via the specific issue's Table of Contents (go to http:// www.minsocam.org/MSA/AmMin/TOC/2020/Nov2020_data/Nov2020_data.html). 